\title{
ВПЛИВ НОВОГО ПОХІДНОГО 4-АМІНОБУТАНОВОЇ КИСЛОТИ НА СТАН СЕНСОМОТОРНОЇ КОРИ ВЕЛИКИХ ПІВКУЛЬ ГОЛОВНОГО МОЗКУ ЩУРІВ ЗА УМОВ ЕКСПЕРИМЕНТАЛЬНОЇ ІШЕМІЇ
}

Вступ. Пошук нових ноотропних препаратів, здатних поліпшувати когнітивні порушення, що виникають у результаті порушення мозкового кровообігу, є актуальним науковим завданням. Перспективними в цьому відношенні вважають нові похідні 4-амінобутанової кислоти, синтезовані в Національному фрармацевтичному університеті, серед 11 з яких було обрано субстанцію-лідер за антиамнестичною активністю під шифром КГМ-5, що проявляє і антигіпоксичну активність.

Мета дослідження - вивчити вплив сполуки КГМ-5 на стан сенсомоторної кори великих півкуль головного мозку щурів на моделі гострого порушення мозкового кровообігу.

Методи дослідження. Проводили гістологічні дослідження стану сенсомоторної кори великих півкуль головного мозку щурів з моделлю гострого порушення мозкового кровообігу (на 6-ту добу), яке викликали шляхом оклюзії лівої загальної сонної артерії. Головний мозок після вилучення з черепа фріксували в $96^{\circ}$ етанолі, потім робили фрронтальний розріз на рівні передніх країв скроневих часток. Зразки заливали у парафін, одну частину фрарбували гематоксилін-еозином, іншу - тіоніном за методом Ніссля. Перегляд мікропрепаратів здійснювали під світловим мікроскопом Granum, мікроффотографуування мікроскопічних зображень - цифрровою відеокамерою Granum ДСМ 310. Фотознімки обробляли на комп'ютері Pentium 2,4GHz за допомогою програми Toup View.

Результати й обговорення. У щурів із гострим порушенням мозкового кровообігу в ділянці сенсомоторної кори великих півкуль головного мозку виявлено ознаки порушення кровообігу: спазм артеріол, венозну гіперемію, перикапілярний набряк; пірамідні нейрони з морфологічними змінами незворотного характеру. Відзначено підвищення кількості гіпер- та гіпохромних нейронів, гліо- $і$ перинейронального індексів та індексу альтерації. Сполука КГМ-5 поліпшувала мозковий кровообіг у щурів із гострим його порушенням, про що свідчило зменшення вираження спазму капілярів та перикапілярного набряку, збільшувала виживання пірамідних нейронів сенсомоторної кори великих півкуль головного мозку, зменшувала відносну частку незворотно змінених клітин, що підтверджено зниженням індексу альтерації нейронів, гліо- та перинейронального сателітного індексів.

Висновки. Встановлено здатність нового похідного 4-амінобутанової кислоти - сполуки КГМ-5 поліпшувати мозковий кровообіг, збільшувати виживання пірамідних нейронів, зменшувати кількість незворотно змінених клітин. Це доводить наявність у сполуки КГМ-5 церебропротективних властивостей, за виразністю яких вона не поступається препарату порівняння “Пікамілон".

КЛЮЧОВІ СЛОВА: нове похідне 4-амінобутанової кислоти; сполука КГМ-5; модель гострого порушення мозкового кровообігу; сенсомоторна кора великих півкуль головного мозку; препарат "Пікамілон".

ВСТУП. До основних захворювань головного мозку, які спричиняють розвиток когнітивної дисорункції, належать нейродегенеративні (хвороба Альцгеймера та ін.), судинні (ішемія головного мозку), черепно-мозкові травми, нейроінфрекції тощо [1, 2]. Порушення мозкового кровообігу є другою за частотою після хвороби Альцгеймера причиною деменції. Судинна деменція становить від 10 до 30 \% у загальній структурі деменцій [1]. Судинні порушення призводять до зміни мозкового кровообігу з розвитком гіпоксії тканин мозку, порушенням живлення та енергозабезпечення нейронів, що сприяє розвитку ( О. Я. Міщенко, Н. Ю. Палагіна, Ю. Б. Лар'яновська, 2021. внутрішньоклітинних біохімічних змін і дифрузного мультисрокального ураження головного мозку [3]. Для лікування когнітивних розладів у комплексній терапії широко використовують церебропротектори, ноотропи, які не завжди ефективні й безпечні [4]. Тому пошук нових ноотропних препаратів, здатних поліпшувати когнітивні порушення, що виникають у результаті гострого або хронічного порушення мозкового кровообігу, $€$ актуальним науковим завданням. Перспективними в цьому відношенні вважають нові похідні 4-амінобутанової кислоти, синтезовані в Національному фрармацевтичному університеті, серед 11 я яких було обрано субстанцію-лідер за анти- 
амнестичною активністю під шифрром КГМ-5, що проявляє також і антигіпоксичну активність [5]. 3 огляду на вищесказане, доцільним є вивчити ії здатність покращувати порушений стан головного мозку щурів за умов експериментальної ішемії.

Мета дослідження - вивчити вплив сполуки КГМ-5 на стан сенсомоторної кори великих півкуль головного мозку щурів на моделі гострого порушення мозкового кровообігу.

МЕТОДИ ДОСЛІДЖЕННЯ. Досліджено морфрофрункціональний стан сенсомоторної кори (СМК) великих півкуль головного мозку щурів віком 15 місяців з моделлю гострого порушення мозкового кровообігу (ГПМК), яку відтворювали шляхом перманентної оклюзії лівої загальної сонної артерії [6], - контрольна патологія; аналогічні ділянки мозку 15-місячних тварин, яким протягом 5 діб після оперативного втручання вводили сполуку КГМ-5 в умовно-ефективній дозі 30 мг/кг, і тварин, які отримували препарат порівняння “Пікамілон” (розчин для ін'єкцій 100 мг/мл, виробництва ОАО "Фармстандарт УфраВИТА", РФ) у дозі 17 мг/кг, розрахованій з добової дози для людини (200 мг/добу) з використанням коефіцієнта видової чутливості [7]. Як контроль було досліджено ділянку СМК великих півкуль головного мозку хибно-оперованих тварин. Виводили тварин 3 експерименту на 6-ту добу після моделювання ГПМК (через добу після останнього введення досліджуваних засобів). Головний мозок безпосередньо після вилучення 3 порожнини черепа фріксували в 96 етанолі, потім робили фрронтальний розріз на рівні передніх країв скроневих часток (для дослідження СМК). Зразки заливали у парафін. Зрізи для оглядової мікроскопії фрарбували гематоксилінеозином [8], зрізи для визначення фрункціональної активності нейронів - тіоніном за методом Ніссля [9]. Як морфологічні критерії оцінки стану СМК великих півкуль головного мозку, крім якісного аналізу, використовували окремі кількісні показники - розподіл пірамідних нейронів за основними структурно-функціональними типами, які виявляли згідно з класифрікацією $[10,11]$. Визначали їх відносну кількість (перераховували на 100 клітин); розраховували індекс альтерації (відношення деструктивних нейронів до незмінених), гліонейрональний (відношення числа гліальних елементів до пірамідних нейронів) i перинейрональний сателітний (кількість клітин сателітної глії на один пірамідний нейрон) індекси [12]. Аналіз проводили в 3-му і 5-му шарах неокортексу - саме ці шари є найбільш функціонально активними, і їх найчастіше досліджують у різних експериментах [13]. Перегляд мікропре- паратів здійснювали під світловим мікроскопом Granum, мікрофротографрування мікроскопічних зображень - цисрровою відеокамерою Granum ДСМ 310. Фотознімки обробляли на комп'ютері Pentium 2,4GHz за допомогою програми Тоup View. Статистичну обробку проводили із застосуванням програми STATISTICA 6.0 (StatSoft, Inc., США), перевіряли нормальність розподілу з використанням W-критерію Шапіро - Уїлка. Було встановлено, що дані підлягають ненормальному розподілу, тому використовували непараметричний U-критерій Манна - Уїтні, результати представляли як медіану (Ме) та інтерквартильний розмах (процентилі 25-75). Прийнято рівень значущості $p<0,05$. Для отримання статистичних висновків застосовували стандартний пакет програм STATISTICA [14]. Під час проведення експериментів дотримано принципів Гельсінської декларації щодо гуманного поводження з тваринами (2000р.) та Директиви Ради Європейського Союзу щодо захисту тварин, які використовуються 3 науковою метою (2010 р.) $[15,16]$. Роботу виконано на базі Навчально-наукового тренінгового центру медико-біологічних досліджень Навчально-наукового інституту прикладної фрармації НФаУ (м. Харків, Україна).

РЕЗУЛЬТАТИ Й ОБГОВОРЕННЯ. Кора ГОловного мозку - це нервовий центр, в який надходять сигнали від усіх головних сенсорних зон і діяльність якого забезпечує регуляцію різноманітних функцій організму та складні форми поведінки [17]. На досліджених мікропрепаратах ділянки СМК великих півкуль головного мозку хибно-оперованих щурів гістологічна структура відповідала всім особливостям, які описано в літературі. М'яка мозкова оболонка, що вкриває поверхню мозку, мала звичайний вигляд. Вона вкрита безперервним шаром клітин плоского епітелію. Численні її кровоносні судини помірно повнокровні. У речовині мозку простежено всі облігатні шари, ламінарна (пошарова) будова яких не змінена: молекулярний, зовнішній зернистий, зовнішній пірамідний, внутрішній зернистий, внутрішній пірамідний та поліморфний. Лапідарність (чіткість) і вертикальне впорядкування нервових клітин у шарах збережені. Практично всі нейрони в різних шарах мали чітке клітинне тіло, рівний контур, ядро центрально розташоване, хроматин неконденсованого типу. Ядерце одне, локалізоване в центрі ядра. Нейропіль мав безструктурний вигляд (рис. 1, a, б). Кровоносні судини, капіляри, що пронизують нейропіль, були нормального діаметра. На мікропрепаратах практично всіх контрольних щурів видно невиразні ознаки перицелюлярного та 
перикапілярного набряку артефіціального характеру. Клітини глії розташовані як поодиноко, так і у вигляді дрібних (не більше 2-3 клітин) скупчень, а також іноді перинейронально (в основному одна клітина) - сателіти (рис. 1, в). Ці сателіти інколи досить тісно стикалися 3 нейронами. Проведена морфометрія показала, що гліо- і перинейрональний індекси в хибно-оперованих щурів дорівнювали 0,71 та 1,33 відповідно (табл. 1), що укладається в межі норми для даного виду тварин [17].

Фарбування тіоніном за методом Ніссля показало, що в перикаріоні більшості пірамідних нейронів тигроїд мав вигляд базофільних дрібних грудок і досить рівномірно заповнював нейроплазму - нормохромні нейрони (синя нейроплазма, світле ядро). Нечасто траплялися гіперхромні (темно-синя нейроплазма, темно-синє ядро) і гіпохромні (світла нейроплазма, світле ядро) клітини (рис. 1, г). Крім того, дуже рідко виявляли пірамідні нейрони з деструктивними змінами: гіперхромні пікноморфні - зменшені в розмірі, фрорма змінена, зморщена, мають темно-синю нейроплазму, межі ядра невидно, клітини-тіні - глибоке розрідження, запустілість нейроплазми. Такі зміни в стані тигроїду відображають різний фрункціональний стан нейронів.
Так, нормохромні нейрони - це клітини, що перебувають у стані помірної активності [10]. Гіперхромні нейрони, за даними літератури [12], відображають функціональний стан, який характеризується зменшеною синтетичною активністю. У них знижений синтез РНК. Припускають, що дані клітини являють собою неактивний пул нейронів, за рахунок яких після різного впливу (в тому числі гіпоксії) відновлюються фрункції мозку [18]. Гіпохромні нейрони - це клітини, що тривало перебували на піку активності, й на даний момент у них відбуваються виснаження деяких ультраструктур і, відповідно, зниження фрункціональної активності [19]. Проведений кількісний розподіл нейронів різного функціонального стану показав, що нормохромні нейрони становили 82,1 \%, гіпер- та гіпохромні клітини - 9,7 і 6,7 \% відповідно, гіперхромні пікноморфні та клітини-тіні не перевищували $0(0 ; 3,1)$ та $0(0 ; 3) \%$. Індекс альтерації дорівнював $0(0 ; 0)$ (табл. 2).

На 6-ту добу після моделювання ГПМК у щурів групи контрольної патології у мозковій тканині СМК чіткість та вертикальне впорядкування шарів нейронів зберігалися. Спостерігали помітні судинні зміни, найбільш характерними 3 яких були спазм капілярів (спадання стінок, ви-
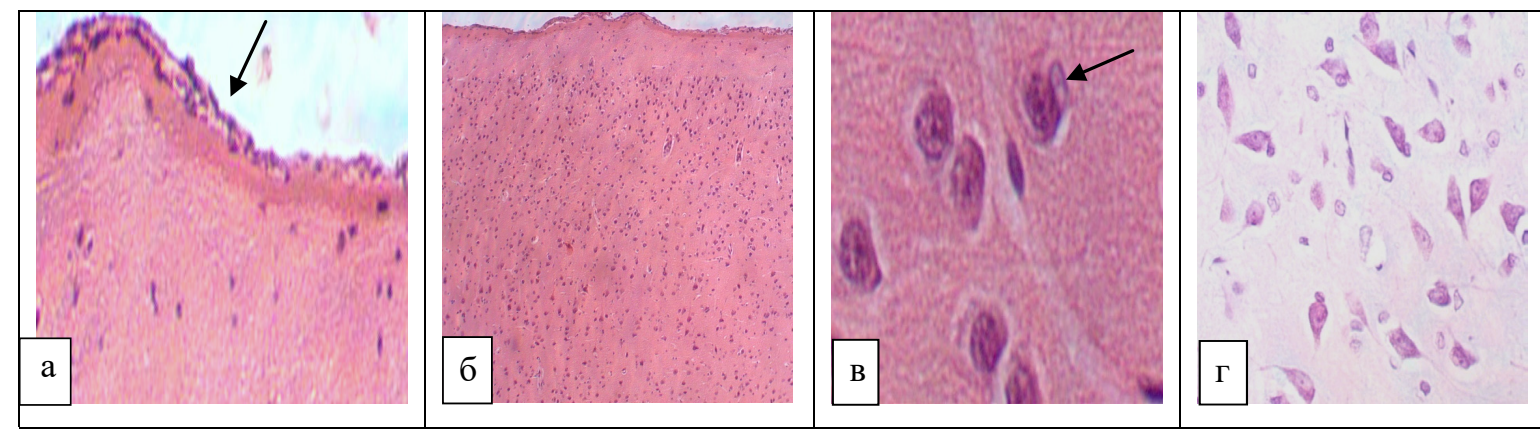

Рис. 1. Мікропрепарат сенсомоторної кори великої півкулі головного мозку хибно-оперованих щурів: а - стан кровоносних судин м'якої мозкової оболонки нормальний (×400); б - цитоархітектоніка шарів збережена, щільність нейропіля звичайна (×100); в - клітина-сателіт (×400). Гематоксилін-еозин; г - переважання нормохромних нейронів, поодинокі гіпер- і гіпохромні клітини (×400). Тіонін за методикою Ніссля.

Таблиця 1 - Виразність гліальної реакції в ділянці сенсомоторної кори великих півкуль головного мозку щурів за умов гострого порушення мозкового кровообігу під впливом досліджуваних засобів $\left(\mathrm{Me}\left(\mathrm{Q}_{25} ; \mathrm{Q}_{75}\right)\right)$

\begin{tabular}{||l|c|c||}
\hline \multirow{2}{*}{\multicolumn{1}{|c|}{ Група досліду }} & \multicolumn{2}{|c|}{ Показник } \\
\cline { 2 - 3 } & $\begin{array}{c}\text { гліонейрональний } \\
\text { індекс }\end{array}$ & $\begin{array}{c}\text { перинейрональний сателітний } \\
\text { індекс }\end{array}$ \\
\hline Хибно-оперовані тварини $(\mathrm{n}=4)$ & $0,71(0,69 ; 0,73)$ & $1,33(1,12 ; 1,5)$ \\
\hline ГПМК (контрольна патологія) $(\mathrm{n}=4)$ & $0,87(0,79 ; 0,9)^{\star}$ & $2,58(2 ; 3)^{\star}$ \\
\hline ГПМК+сполука КГМ-5 $(\mathrm{n}=6)$ & $0,77(0,75 ; 0,79)^{\star / * \star}$ & $2,00(1,33 ; 2)^{\star / *}$ \\
\hline ГПМК+пікамілон $(\mathrm{n}=5)$ & $0,74(0,7 ; 0,78)^{\star / * \star}$ & $1,33(1 ; 2)^{\star \star}$ \\
\hline
\end{tabular}

Примітки. Тут і в таблиці 2:

1. * - відмінності достовірні відносно групи хибно-оперованих тварин ( $<<0,05)$; ** - відмінності достовірні відносно групи контрольної патології $(\mathrm{p}<0,05)$

2. n - кількість тварин у групі. 
Таблиця 2 - Функціональний стан та індекс альтерації в пірамідних нейронах у ділянці сенсомоторної кори великих півкуль головного мозку щурів за умов гострого порушення мозкового кровообігу під впливом досліджуваних засобів (Me $\left.\left(Q_{25} ; Q_{75}\right)\right)$

\begin{tabular}{|c|c|c|c|c|c|c|}
\hline \multirow{2}{*}{$\begin{array}{c}\text { Група } \\
\text { досліду }\end{array}$} & \multicolumn{5}{|c|}{ Основний структурно-фрункціональний тип нейронів, \% } & \multirow[b]{2}{*}{$\begin{array}{c}\text { Індекс } \\
\text { альтерації }\end{array}$} \\
\hline & $\begin{array}{l}\text { нормо- } \\
\text { хромні }\end{array}$ & $\begin{array}{l}\text { гіпер- } \\
\text { хромні }\end{array}$ & $\begin{array}{l}\text { гіперхромні } \\
\text { пікноморфнні }\end{array}$ & $\begin{array}{c}\text { гіпо- } \\
\text { хромні }\end{array}$ & $\begin{array}{l}\text { клітини- } \\
\text { тіні }\end{array}$ & \\
\hline $\begin{array}{l}\text { Хибно-оперовані } \\
\text { тварини }(\mathrm{n}=4)\end{array}$ & $\begin{array}{c}82,1 \\
(80 ; 86,2)\end{array}$ & $\begin{array}{c}9,7 \\
(6,5 ; 10)\end{array}$ & $\begin{array}{c}0 \\
(0 ; 3,1)\end{array}$ & $\begin{array}{c}6,7 \\
(6,3 ; 9,7)\end{array}$ & $\begin{array}{c}0 \\
(0 ; 3)\end{array}$ & $\begin{array}{c}0 \\
(0 ; 0)\end{array}$ \\
\hline $\begin{array}{l}\text { ГПМК (контрольна } \\
\text { патологія) }(\mathrm{n}=4)\end{array}$ & $\begin{array}{c}62,1 \\
(59,3 ; 66,7)^{\star}\end{array}$ & $\begin{array}{c}10,0 \\
(7,4 ; 13,3)\end{array}$ & $\begin{array}{c}12,5 \\
(6,7 ; 14,8)^{\star}\end{array}$ & $\begin{array}{c}9,4 \\
(3,7 ; 10)\end{array}$ & $\begin{array}{c}9,4 \\
(6,7 ; 10,3)^{\star}\end{array}$ & $\begin{array}{c}0,3 \\
(0,3 ; 0,4)^{\star}\end{array}$ \\
\hline $\begin{array}{l}\text { ГПМК+сполука } \\
\text { КГМ-5, } 30 \text { мг/кг } \\
(\mathrm{n}=6)\end{array}$ & $\begin{array}{c}71,0 \\
(66,7 ; 75)^{\star / \star \star}\end{array}$ & $\begin{array}{c}10,0 \\
(9,7 ; 12,5)\end{array}$ & $\begin{array}{c}6,7 \\
(3,7 ; 9,4)^{\star / \star \star}\end{array}$ & $\begin{array}{c}6,7 \\
(3,4 ; 9,4)\end{array}$ & $\begin{array}{c}3,5 \\
(3,2 ; 7,4)^{\star / * \star}\end{array}$ & $\begin{array}{c}0,2 \\
(0,1 ; 0,2)^{\star / \star \star}\end{array}$ \\
\hline $\begin{array}{l}\text { ГПМК+пікамілон } \\
(\mathrm{n}=5)\end{array}$ & $\begin{array}{c}73,5 \\
(72,4 ; 75)^{\star / \star \star} \\
\end{array}$ & $\begin{array}{c}9,7 \\
(6,5 ; 10) \\
\end{array}$ & $\begin{array}{c}3,7 \\
(2,9 ; 6,7)^{\star / \star \star} \\
\end{array}$ & $\begin{array}{c}9,4 \\
(6,9 ; 10) \\
\end{array}$ & $\begin{array}{c}5,9 \\
(0 ; 6,9)^{\star / \star \star}\end{array}$ & $\begin{array}{c}0,1 \\
(0,1 ; 0,2)^{\star / \star \star} \\
\end{array}$ \\
\hline
\end{tabular}

бухання ядер ендотеліоцитів у просвіт, звивистість контурів), перикапілярний набряк. Виник перицелюлярний набряк - найбільш виразний у зовнішньому пірамідному шарі (рис. 2, а).

Була дещо посилена гліальна реакція - дрібні скупчення клітин глії (до 4-5 клітин). Частіше виявляли сателітоз, при цьому нерідко спостерігали зростання числа клітин-сателітів навколо одного нейрона (рис. 2, б). Часто відзначали цитофрагічну діяльність клітин глії - нейронофагію (рис. 2, в). Відмічали збільшення характерного для гіпоксії [20] гомотипового попарного розташування нейронів, що доволі рідко спостерігали в контрольних хибно-оперованих щурів (рис. 2, б). Перинейрональний сателітний індекс у щурів цієї групи підвищився майже на 94 \%. Збільшився на 22,5\% і гліонейрональний індекс (табл. 1). Зростання цих індексів пов'язують із втратою нейронами пластичних та біоенергетичних запасів (вони поповнюються за рахунок і через контакти з гліальними клітинами-сателітами) та, як наслідок, з підвищенням рівня напруги нейронів. Саме ж зростання даних індексів морфологічно розцінюють як компенсаторну (у відповідь на ушкодження) неспецифічну гліаль- ну реакцію [21]. Крім судинних змін і неспецифрічної гліальної реакції, виявлено цитотоксичні зміни певної частини нейронів, які характеризувалися некротичними проявами за типом коагуляційного пікноморфного некрозу та колікваційних ушкоджень із фрормуванням клітин-тіней. При фрарбуванні тіоніном відмічено помітне збільшення кількості гіперхромних нейронів, появу серед них клітин, які втрачали характерну фрорму, ядро не визначалося, контури тіла були нечіткими гіперхромні пікноморфні нейрони. Згідно з даними літератури, гіперхромні пікноморфні нейрони вважають патологічними, незворотно зміненими [22]. Помітно зростала кількість гіпохромних нейронів і клітин-тіней. Іноді на місці нейрона було видно лише блідо пофрарбовані залишки нейроплазми (рис. 2, г). Серед пірамідних нейронів видно також клітини з вакуолізацією нейроплазми, центральним або периферичним хроматолізом тигроїду в перикаріоні.

Кількісні розрахунки підтвердили зміни фрункціонального стану нейронів: нормохромних нейронів вірогідно ставало менше (на 24,4 \%), відносна кількість незворотно змінених нейронів (гіперхромних пікноморфних та клітин-тіней)
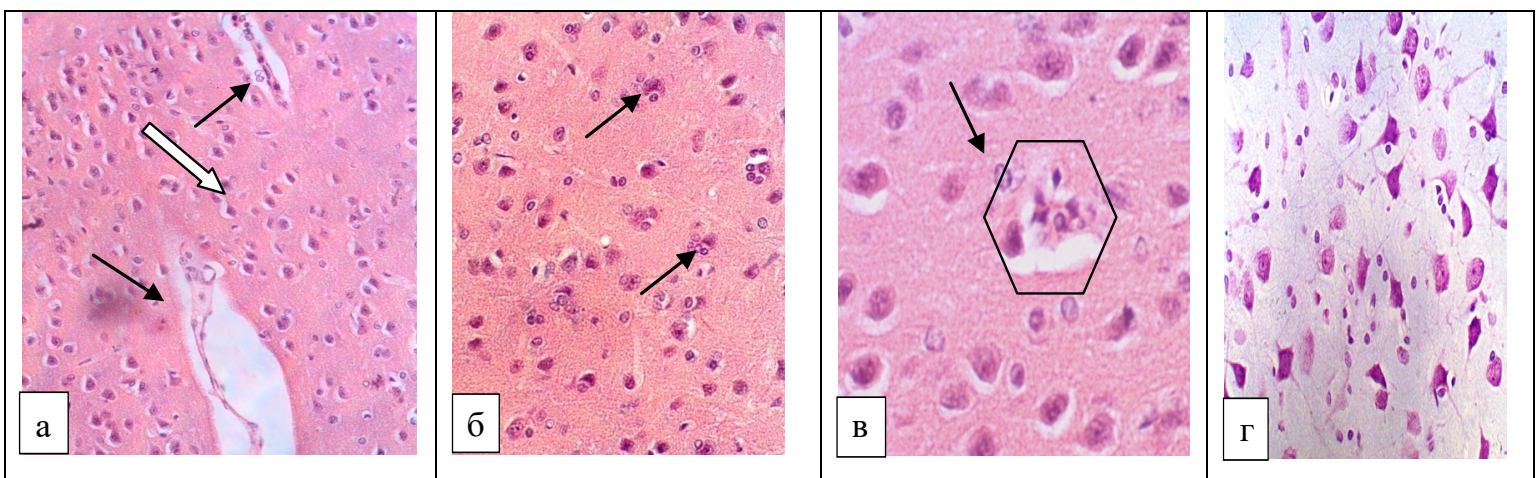

Рис. 2. Мікропрепарат сенсомоторної кори великої півкулі головного мозку щурів на 6-ту добу після моделювання гострого порушення мозкового кровообігу: а - спазм капілярів, перикапілярний набряк (×250); б - посилення гліальної реакції (стрілки, ×250); в - нейронофагія (стрілка, ×400). Гематоксилін-еозин. г - збільшення кількості гіперхромних пікноморфних нейронів, клітин-тіней, зменшення числа нормохромних нейронів (×400). Тіонін за методом Ніссля. 
достовірно зростала (у 12,5 і 9,4 раза). Кількість клітин з метаболічними порушеннями (гіпер- та гіпохромних) дещо збільшувалася, але це не мало вірогідного характеру. Індекс альтерації становив $0,329(0,3 ; 0,4)$, що достовірно перевищувало такий у хибно-оперованих щурів (табл. 2).

Лікування щурів із ГПМК протягом 5 діб сполукою КГМ-5 помітно зменшувало ознаки порушення кровообігу в ділянці СМК великих півкуль головного мозку: спазм капілярів (у жодному 3 полів зору мікроскопа не спостерігали судин 3 діаметром, меншим ніж 10 мкм, що дає підстави характеризувати їх як ті, що фуннкціонують [23]), периваскулярний набряк. Судини м'якої мозкової оболонки були переважно помірного кровонаповнення (рис. 3, а). Перицелюлярний набряк не значний, гомотипове розташування нейроцитів не велике. Майже не простежували ознак нейронофагії. Відзначали концентрацію незмінених нейронів і клітин глії поблизу кровоносних капілярів, що, за даними літератури [24], можна розглядати як адаптаційні механізми виживання клітин за умов ішемії. Послабилась, порівняно зі щурами з ГПМК без лікування, гліальна реакція у вигляді дрібних скупчень гліальних клітин та збільшеного перинейронального гліального оточення (рис. 3, б), що підтвердили показники гліонейронального $(0,77)$ та перинейронального (2) індексів, які були достовірно меншими порівняно з тваринами групи контрольної патології (табл. 1).

Фарбування тіоніном за методом Ніссля показало, що, незважаючи на наявність багатьох нормохромних нейронів, у цілому ряді полей зору на ділянці СМК спостерігали гіпер- і гіперхромні пікноморфні нейрони (рис. 3, в, г), де-не-де помітними були хроматоліз нейроплазми та клітини-тіні. Морфометричні виміри підтвердили візуальну картину. Достовірно збільшилася кіль- кість нормохромних нейронів на $14,33 \%$. На 46,4 \% було менше гіпохромних пікноморфнних нейронів, на 62,8 \% - клітин-тіней порівняно 3 тваринами групи контрольної патології. Індекс альтерації пірамідних нейронів цієї ділянки головного мозку тварин під впливом сполуки КГМ-5 був достовірно нижчим (33,33 \%) порівняно 3 контрольною патологією (табл. 2).

Після введення препарату порівняння “Пікамілон" щурам із ГПМК судини м'якої мозкової оболонки в ділянці СМК великих півкуль головного мозку були переважно помірного кровонаповнення, не спостерігали спазму капілярів. У просвіті судин чітко видно вільно розташовані еритроцити. Периваскулярний набряк дуже обмежений, часто в безпосередній близькості до судини видно скупчення нейронів та клітин глії (рис. 4, а). Помітно меншими ставали перицелюлярний набряк, гомотипове розташування нейроцитів (рис. 4, б). Ознак некрофагії не виявлено. Гліальна реакція у вигляді дрібних скупчень гліальних клітин та перинейронального гліального оточення була послаблена. Гліонейрональний індекс дорівнював $0,74(0,7 ; 0,78)$, перинейрональний індекс - $1,33(1 ; 2)$, що на 14,9 і 48,4 \% менше порівняно з тваринами групи контрольної патології (табл. 1).

Фарбування тіоніном показало, що багато нейронів характеризувалося нормохромним станом, гіперхромних і гіперхромних пікноморорних нейронів візуально було небагато, як і виразно гіпохромних клітин. Відмічали вакуолізацію нейроплазми частини нейронів на тлі нормохромного стану тигроїду (рис. 4, в, г).

За морфометричними вимірами, достовірно відносна частка нормохромних нейронів зросла на 18,4 \%, частка гіперхромних пікноморфнних нейронів і клітин-тіней зменшилася у 3,4 й 1,6 раза проти контрольної патології. Індекс альтерації знизився у 2 рази (табл. 2).

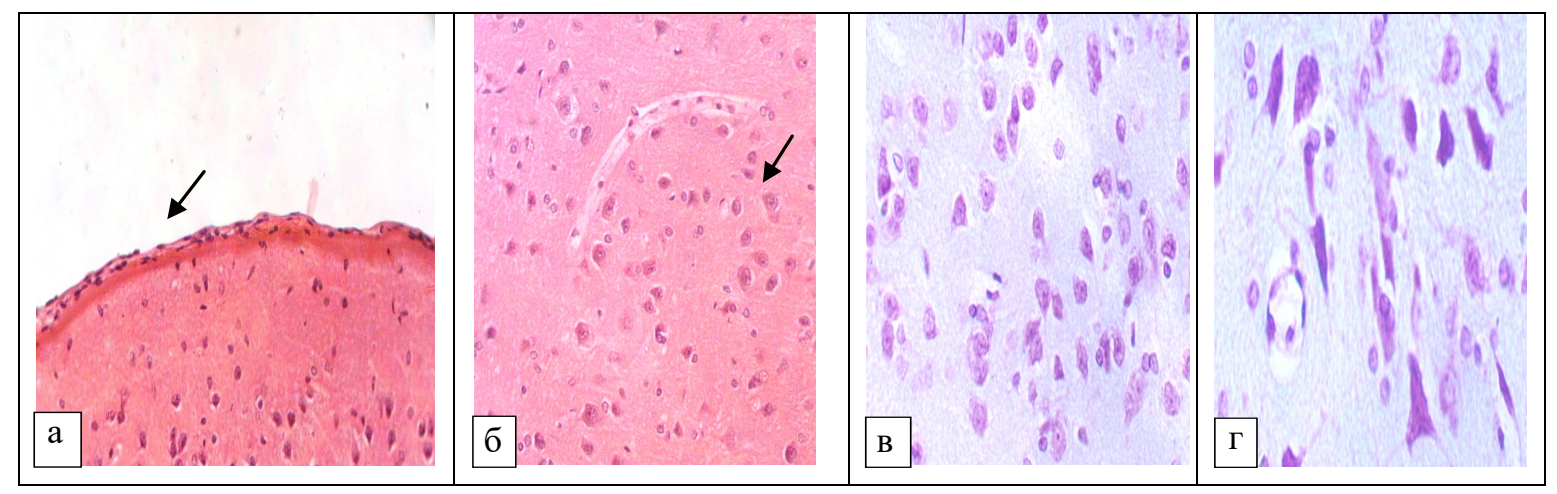

Рис. 3. Мікропрепарат сенсомоторної кори великої півкулі головного мозку щурів, які на тлі гострого порушення мозкового кровообігу отримували сполуку КГМ-5: а - нормальний стан м'якої мозкової оболонки; б - відсутність спазму кровоносних капілярів, виразне зменшення перикапілярного і перицелюлярного набряку. Гематоксилін-еозин. ×250; в - нормохромні нейрони; г - гіпер- та гіпохромні пікноморфнні нейрони. Тіонін за методом Ніссля. ×400. 


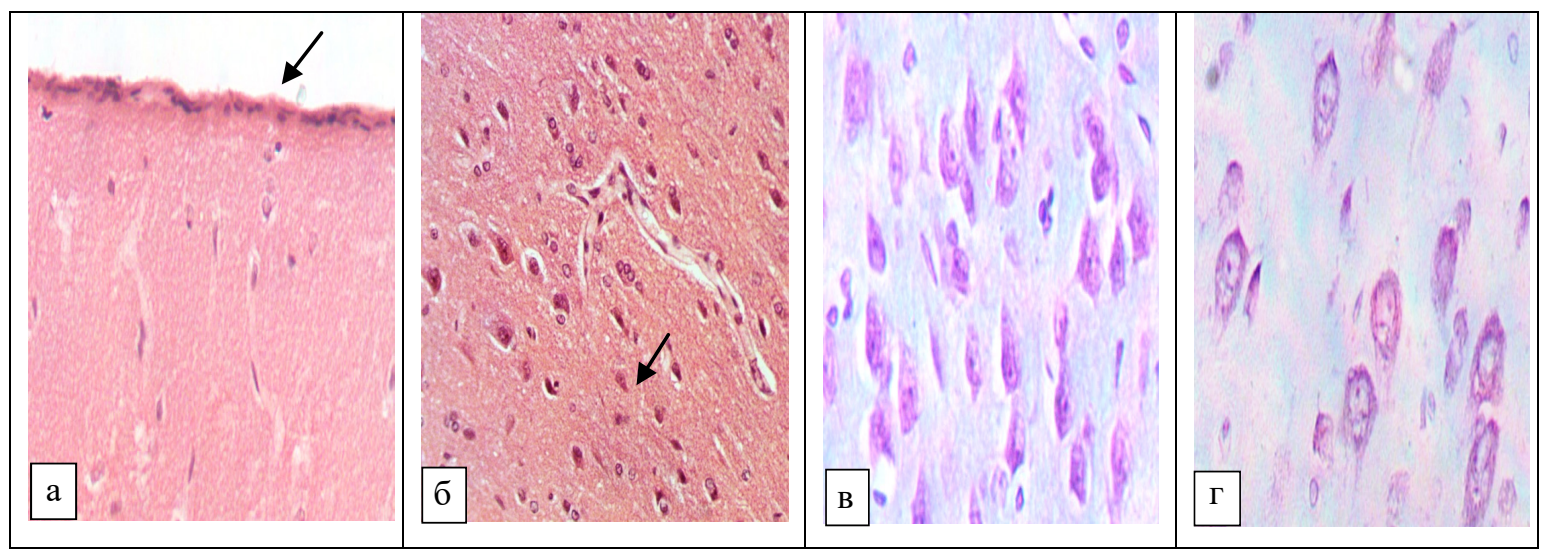

Рис. 4. Мікропрепарат сенсомоторної кори великої півкулі головного мозку щурів, які на тлі гострого порушення мозкового кровообігу отримували препарат “Пікамілон”: а - нормальний стан м'якої мозкової оболонки; б - відсутність спазму кровоносних капілярів, виразне зменшення перикапілярного набряку. Гематоксилін-еозин. ×250; в - переважання нормохромних нейронів, поодинокі гіперхромні клітини, клітини-тіні; г - вакуолізація нормохромних нейронів, клітинитіні. Тіонін за методом Ніссля. х400.

Отже, на 6-ту добу після перманентного перев'язування лівої сонної артерії (ГПМК) у щурів зрілого репродуктивного віку (15 місяців) у ділянці СМК великих півкуль головного мозку виявлено: ознаки порушення кровообігу у вигляді спазму артеріол, венозної гіперемії, перикапілярного набряку; пірамідні нейрони з морфологічними змінами незворотного характеру, що призвело до виразного підвищення індексу альтерації цих нейронів. Серед пірамідних нейронів, що вижили, спостерігали збільшення кількості клітин з метаболічними порушеннями (гіпер- та гіпохромних). Цитотоксичні зміни супроводжувалися компенсаторною неспецифічною гліальною реакцією (зростанням гліо- та перинейронального індексів), що вказувало на виразне збільшення передачі гліальних поживних речовин у тіла нервових клітин.

Лікування щурів із ГПМК сполукою КГМ-5 поліпшувало мозковий кровообіг, про що свідчи-

\section{СПИСОК ЛІТЕРАТУРИ}

1. Камчатнов П. Р. Ведение больных с когнитивными нарушениями / П. Р. Камчатнов, Х. Я. Умарова, А. В. Чугунов // Нервные болезни. - 2015. - № 4. C. $18-22$.

2. Ковальчук В. В. Когнитивная диссункция. Современный взгляд на этиопатогенез, диагностику и терапию / В. В. Ковальчук // Эфрфективная фрармакотерапия. - 2020. - 16, № 31. - С. 40-52.

3. Когнитивные расстройства в неврологической клинике / Н. Н. Яхно // Неврол. журн. - 2006. - 11. Приложение 1. - С. 4-12. ло зменшення виразності спазму капілярів і перикапілярного набряку. Лікувальне введення сполуки КГМ-5 збільшувало виживання пірамідних нейронів досліджених ділянок головного мозку, зменшувало відносну частку незворотно змінених клітин, що підтверджено зниженням індексу альтерації нейронів. Очевидно, це забезпечило і зменшення гліо- та перинейронального сателітного індексів. Усе вищесказане дозволяє говорити про наявність у сполуки КГМ-5 церебропротективних властивостей.

ВИСНОВОК. Встановлено здатність нового похідного 4-амінобутанової кислоти - сполуки КГМ-5 поліпшувати мозковий кровообіг, збільшувати виживання пірамідних нейронів, зменшувати кількість незворотно змінених клітин. Це доводить наявність у сполуки КГМ-5 церебропротективних властивостей, за виразністю яких вона не поступається препарату порівняння “Пікамілон".
4. Ковальчук В. В. Хроническая ишемия головного мозга. Современные представления об этиопатогенезе, диагностике и терапии / В. В. Ковальчук, Е. Р. Баранцевич // Эффрективная фрармакотерапия. 2017. - № 19. - С. 26-32.

5. Пат. України на корисну модель 120512, МПК (206), А 61К 31/197. Застосування похідних 4-амінобутанової кислоти як антиамнестичних засобів / Міщенко О. Я., Голік М. Ю., Гриценко І. С. та ін. ; заявник і патентовласник НФаУ. - № u201703627 ; заявл. 13.04.17 ; опубл. 10.11.17, Бюл. № 21. 
6. Руководство по проведению доклинических исследований лекарственных средств / под ред. А. Н. Миронова. - М. : Гриср и К, 2012. - Часть первая. -944 с.

7. Уланова И. П. К вопросу об учете поверхности тела экспериментальных животных при токсикологическом исследовании / И. П. Уланова, К. К. Сидоров, А. И. Халепо // Токсикология новых промышленных химических веществ. - Л. : Медицина, 1968. Вып. 10. - С. 18-25.

8. Меркулов Г. А. Курс патологогистологической техники / Г. А. Меркулов. - М. : Медицина, Ленингр. отд-ние, 1969. - 424 с. 962 c.

9. Пирс Э. Гистохимия / Э. Пирс. - М., 1962. -

10. Каптарь В. С. Влияние полидана и пирацетама на условнорефрлекторную память и структурно-функциональное состояние нейронов неокортеса крыс : автореср. дисс. на соискание учен. степени канд. биол. наук / В. С. Каптарь. - М., 2007. - 24 с.

11. Петров А. В. Морфологические формы адаптационной изменчивости нервных клеток при действии антропогенных фракторов / А. В. Петров, В. П. Федоров // Новости клинич. цитологии России. - 1998. 2, № 2. - С. 83-84.

12. Медико-биологические исследования в гигиене / [Р. В. Меркурьева, К. В. Суданов, Т. И. Бонашевская и др.]. - М. : Медицина, 1986. - 272 с.

13. Мац В. Н. Нейроно-глиальные соотношения В неокортексе при обучении / В. Н. Мац. - М. : Наука, 1994. - 95 c.

14. Халасрян A. A. STATISTICA 6. Статистический анализ данных : учебник / А. А. Халафян. - 3-е изд. М. : ООО “Бином-Пресс", 2007. - 512 с.

15. Про затвердження Порядку проведення доклінічного вивчення лікарських засобів : наказ МОЗ України від 14.12.2009 р. № 944 [Електронний ресурс]. - Режим доступу : https://zakon.rada.gov.ua/laws/ show/z0053-10\#Text.

16. European convention for the protection of vertebrate animal used for experimental and other scientific purposes. - Council of Europe, Stratsburg, 1986. - 11 p.
17. Арушанян Э. Б. Гиппокамп и нарушения познавательной деятельности / Э. Б. Арушанян, Э. В. Бейер // Журн. неврологии и психиатрии им. С. С. Корсакова. 2007. - № 107 (7). - С. 72-77.

18. Морфологические изменения нейронов головного мозга крыс при двух-, четырёхсосудистой моделях ишемического повреждения головного мозга крыс и их коррекция тадалафилом в эксперименте [Электронный ресурс] / О. В. Мартынова, А. В. Тверской, М.В.Покровский [и др.] // Современные проблемы науки и образования. - 2016. - № 6. - URL : http://www.science-education.ru/ru/article/view?id=25953 (дата обращения: 24.03.2021).

19. Калимуллина Л. Б. К вопросу о "темных" и "светлых" клетках / Л. Б. Калимуллина // Морфология. - 2002. - 122, № 4. - С. 75-79.

20. Гуляев С. М. Морфологическая оценка церебропротекторного действия лантана ацетата при хронической ишемии головного мозга у крыс / С. М. Гуляев, И. О. Убашеев, Н. М. Кожевникова // Морфология. - 2007. - 132, № 4. - С. 24-27.

21. Наумов Н. Г. Реактивные изменения мезокортиколимбической досраминергической системы мозга при экспериментальной гипоксии и ее коррекции : дисс. ... канд. мед. наук : 03.03.04 / Наумов Николай Георгиевич. - СПб., 2017. - 168 с.

22. Степанов А. С. Сравнительная характеристика синаптоархитектоники неокортекса, гиппокампа и миндалевидного комплекса белых крыс в норме и после острой ишемии / А. С. Степанов // Журн. анатомии и гистопатологии. - 2017. - № 6 (4) . - С. 47-54.

23. Афррикян Ш. Г. Влияние ноопепта на церебральную гемодинамику и нейроповеденческие последствия ишемических нарушений мезга : дисс. ... канд. фрармац. наук / Афррикян Шушаник Геворковна. Ереван, 2015. - 134 с.

24. Монид М. В. Фармакологическая коррекция постишемических повреждений лимбических структур головного мозга по данным морфологического анализа : автореф. дисс. на соискание учен. степени канд. мед. наук / М. В. Монид. - СПб., 2015. - 25 с.

\section{REFERENCES}

1. Kamchatnov, P.R., Umarova, H.Ya., \& Chugunov, A.V. (2015). Vedenie bolnykh s kognitivnymi narusheniyami [Management of patients with cognitive impairment]. Nervnye bolezni - Nervous Diseases, 4, 18-22 [in Russian].

2. Kovalchuk, V.V. (2020). Kognitivnaya disfunktsiya. Sovremennyy vzglyad na etiopatogenez, diagnostiku i terapiyu [Cognitive dysfunction. Modern view of etiopathogenesis, diagnosis and therapy]. Effektivnaya farmakoterapiya - Effective Pharmacotherapy, 16 (31), 40-52. DOI 10.33978/2307-3586-2020-16-31-40-52 [in Russian].

3. Yahno, N.N. (2006). Kognitivnye rasstroystva v nevrologicheskoy klinike [Cognitive disorders in a neuro- logical clinic]. Nevrologicheskiy zhurnal - Neurological Journal, 11, 1, 4-12 [in Russian].

4. Kovalchuk, V.V., \& Barantsevich, E.R. (2017). Khronicheskaya ishemiya golovnogo mozga. Sovremennye predstavleniya ob etiopatogeneze, diagnostike i terapii [Chronic cerebral ischemia. Modern concepts of etiopathogenesis, diagnosis and therapy]. Effektivnaya farmakoterapiya - Effective Pharmacotherapy, 19, 26-32 [in Russian].

5. Patent of Ukraine on the utility model 120512 [Patent Ukrainy na korysnu model №120512; MPK (206), A $61 \mathrm{~K}$ 31/197. Zastosuvannia pokhidnykh 4-aminobutanovoi kysloty yak antyamnestychnykh zasobiv]. Mishchenko, O.Ya., Holik, M.Yu., Hrytsenko, I.S.; zaiav- 
nyk i patentovlasnyk NFaU. № u201703627; zaiavl. 13.04.2017; opub. 10.11.2017. [in Ukrainian].

6. Mironov, A.N. (Ed.). (2012). Rukovodstvo po provedeniyu doklinicheskikh issledovaniy lekarstvennykh sredstv [Guidelines for conducting preclinical studies of medicinal funds]. Moscow: Grif i K [in Russian].

7. Ulanova, I.P., Sidorov, K.K., \& Halepo, A.I.K. (1968). Voprosy ob uchete poverhnosti tela eksperimentalnykh zhivotnykh pri toksikologicheskom issledovanii [On the issue of taking into account the body surface of experimental animals in toxicological research.]. Toksikologiya novykh promyshlennykh khimicheskikh veshchestv. Leningrad: Meditsina [in Russian].

8. Merkulov, G.A. (1969). Kurs patologogistologicheskoy tekhniki [Course of pathologic-histological technique]. Moscow: Meditsina Leningr. otd-nie [in Russian].

9. Pirs, E. (1962). Gistokhimiya [Histochemistry]. Moscow [in Russian].

10. Kaptar, V.S. (2007). Vliyanie polidana i piratsetama na uslovnoreflektornuyu pamyat i strukturno-funktsionalnoe sostoyanie neyronov neokortesa krys [Effect of polydan and piracetam on conditioned reflex memory and structural and functional state of neurons in rat neocortes]. Extended abstract of Candidate's thesis. Moscow [in Russian].

11. Petrov, A.V., \& Fedorov, V.P. (1998). Morfologicheskie formy adaptatsionnoy izmenchivosti nervnykh kletok pri deystvii antropogennykh faktorov [Morphological forms of adaptive variability of nerve cells under the action of anthropogenic factors]. Novosti klinicheskoy tsitologii Rossii - News of Clinical Cytology of Russia, 2, 2, 83-84 [in Russian].

12. Merkureva, R.V., Sudanov, K.V., Bonashevskaya, T.I., \& Zhurkov, V.S. (1986). Mediko-biologicheskie issledovaniya v gigiene [Biomedical research in hygiene]. Mocow: Meditsina [in Russian].

13. Mats, V.N. (1994). Neyrono-glialnyie sootnosheniya v neokortekse priobuchenii [Neuron-glial relationships in the neocortex during learning]. Moscow: Nauka [in Russian].

14. Halafyan, A.A. (2007). STATISTICA 6. Statisticheskiy analiz dannykh. 3-e izd. Uchebnik [Statistical data analysis. 3rd ed. Textbook]. Mocow: OOO "BinomPress" [in Russian].

15. Nakaz MOZ Ukrainy № 944 "Pro zatverdzhennia Poriadku provedennia doklinichnoho vyvchennia likarskykh zasobiv" vid 14.12.2009 roku [On approval of the Procedure for conducting preclinical study of drugs: order of the Ministry of Health of Ukraine dated December 14, 2009 No. 944]. Retrieved from: https://zakon.rada.gov. ua/laws/show/z0053-10\#Text [in Ukrainian].

16. (1986). European convention for the protection of vertebrate animal used for experimental and other scientific purposes. Council of Europe, Stratsburg.

17. Arushanyan, E.B., \& Beyer, E.V. (2007). Gippokamp i narusheniya poznavatelnoy deyatelnosti
[The hippocampus and cognitive impairment]. Zhurn. nevrologii i psikhiatrii im. S.S. Korsakovaa - Journal of Neurology and Psychiatry by S.S. Korsakov, 107 (7), 72-77 [in Russian].

18. Martynova, O.V., Tverskoy, A.V., \& Pokrovsky, M.V. (2016). Morfologicheskiye izmeneniya neyronov golovnogo mozga krys pri dvukh-, chetyrokhsosudistoy modelyakh ishemicheskogo povrezhdeniya golovnogo mozga krys i ikh korrektsiya tadalafilom v eksperimente [Morphological changes in rat brain neurons in two-, fourvessel models of ischemic brain damage in rats and their correction with tadalafil in the experiment]. Sovremennye problemy nauki i obrzovaniya - Modern Problems of Science and Education, 6. Retrieved from: http://www. science-education.ru/ru/article/view?id=25953 (date of access: 03/24/2021) [in Russian].

19. Kalimullina, L.B. (2002). K voprosu o "temnykh" i "svetlykh" kletkakh [On the question of "dark" and "light" cells]. Morfologiya - Morphology, 122, 4, 75-79 [in Russian].

20. Gulyaev, S.M., Ubasheev, I.O., \& Kozhevnikova, N.M. (2007). Morfologicheskaya otsenka tserebroprotektornogo deystviya lantana atsetata pri khronicheskoy ishemii golovnogo mozga u krys [Morphological assessment of the cerebroprotective effect of lanthanum acetate in chronic cerebral ischemia in rats]. Morfologiya Morphology, 132, 4, 24-27 [in Russian].

21. Naumov, N.G. (2017). Reaktivnye izmeneniya mezokortikolimbicheskoy dofaminergicheskoy sistemy mozga pri eksperimentalnoy gipoksii i ee korrektsii [Reactive changes in the mesocorticolimbic dopaminergic system of the brain during experimental hypoxia and its correction]. Candidate's thesis. Saint-Petersburg [in Russian].

22. Stepanov, A.S. (2017). Sravnitelnaya kharakteristika sinaptoarkhitektoniki neokorteksa, gippokampa i mendalevidnogo kompleksa belykh krys v norme i posle osstroy ishemii [Comparative characteristics of the synaptoarchitectonics of the neocortex, hippocampus and amygdala in white rats in normal conditions and after acute ischemia]. Zhurn. anat. i gipopatol. - Journal of Anatomy and Hypopathology, 6 (4), 47-54 [in Russian].

23. Afrikyan, Sh.G. (2015). Vliyanie noopepta na tserebralnuyu gemodinamiku i neyropovedecheskie posledstviya ishemicheskikh narusheniy mozga [Pharmacological correction of postischemic injuries of the limbic structures of the cerebral pulp according to morphological analysis]. Candidate's thesis. Erevan [in Russian].

24. Monid, M.V. (2015). Farmakologicheskaya korrektsiya postishemicheskih povrezhdeniy limbicheskih struktur golovnogo mezga po dannyam morfologicheskogo analiza [Pharmacological correction of postischemic injuries of the limbic structures of the cerebral pulp according to morphological analysis]. Extended abstract of Candidate's thesis. Saint-Peterburg [in Russian]. 


\section{ВЛИЯНИЕ НОВОГО ПРОИЗВОДНОГО 4-АМИНОБУТАНОВОЙ КИСЛОТЫ НА СОСТОЯНИЕ СЕНСОМОТОРНОЙ КОРЫ ГОЛОВНОГО МОЗГА КРЫС В УСЛОВИЯХ ЭКСПЕРИМЕНТАЛЬНОЙ ИШЕМИИ}

\section{Резюме}

Вступление. Поиск новых ноотропных препаратов, способных улучшать когнитивные нарушения, возникающие в результате нарушения мозгового кровообращения, является актуальной научной задачей. Перспективными в этом плане считают новые производные 4-аминобутановой кислоты, синтезированные в Национальном фрармацевтическом университете, среди 11 из которых была выбрана субстанциялидер по антиамнестической активности под шифром КГМ-5, которая проявляет и антигипоксическую активность.

Цель исследования - изучить влияние соединения КГМ-5 на состояние сенсомоторной коры больших полушарий головного мозга крыс на модели острого нарушения мозгового кровообращения.

Методы исследования. Проводили гистологические исследования состояния сенсомоторной коры больших полушарий головного мозга крыс с моделью острого нарушения мозгового кровообращения (на 6-е сутки), вызванного путем окклюзии левой общей сонной артерии. Головной мозг после извлечения из черепа фриксировали в $96^{\circ}$ этаноле, затем делали фрронтальный разрез на уровне передних краев височных долей. Образцы заливали в парафин, одну часть окрашивали гематоксилин-эозином, другую - тионином по методу Ниссля. Просмотр микропрепаратов осуществляли под световым микроскопом Granum, мuкрофротосъемку микроскопических изображений - цифровой видеокамерой Granum ДСм 310. Фотографрии обрабатывали на компьютере Pentium 2,4GHz с помощью программы Toup View.

Результаты и обсуждение. У крыс с острым нарушением мозгового кровообращения в области сенсомоторной коры больших полушарий головного мозга выявлены признаки нарушения кровообращения: спазм артериол, венозная гиперемия, перикапиллярный отек; пирамидные нейроны с морфологическими изменениями необратимого характера. Отмечено повышение количества гипер- и гипохромных нейронов, глио- и перинейронального индексов и индекса альтерации. Соединение КГМ-5 улучшало мозговое кровообращение у крыс с острым его нарушением, о чем свидетельствовало уменьшение выраженности спазма капилляров и перикапиллярного отека, увеличивало выживаемость пирамидных нейронов сенсомоторной коры больших полушарий головного мозга, уменьшало относительную долю необратимо измененных клеток, что подтверждено снижением индекса альтерации нейронов, глио- и перинейронального сателитного индексов.

Выводы. Установлена способность нового производного 4-аминобутановой кислоты - соединения КГМ-5 улучшать мозговое кровообращение, увеличивать выживаемость пирамидных нейронов, уменьшать количество необратимо измененных клеток. Это доказывает наличие у соединения КГМ-5 церебропротективных свойств, по выразительности которых оно не уступает препарату сравнения “Пикамилон”.

КЛЮЧЕВЫЕ СЛОВА: новое произВодное 4-аминобутановой кислоты; соединение КГМ-5; модель острого нарушения мозгового кровообращения; сенсомоторная кора больших полушарий головного мозга; препарат "Пикамилон".

O. Ya. Mishchenko, N. Yu. Palagina, Yu. B. Larianovska NATIONAL UNIVERSITY OF PHARMACY, KHARKIV

\section{INFLUENCE OF A NEW DERIVATIVE OF 4-AMINOBUTANOIC ACID ON THE STATE OF THE SENSOMOTOR CORE OF THE BRAIN OF RATS IN THE CONDITIONS OF EXPERIMENTAL ISCHEMIA}

\section{Summary}

Introduction. The search for new nootropic drugs that can improve cognitive impairment resulting from cerebral circulatory disorders is an urgent scientific task. Promising in this regard are new derivatives of 4-aminobutanoic acid, synthesized at the National University of Pharmacy, among 11 was selected the leading substance for antiamnestic activity under the code KGM-5, which also exhibits antihypoxic activity. 
The aim of the study - to investigate the effect of the compound KGM-5 on the condition of the sensorimotor cortex (SMC) of the brain of rats in a model of acute cerebrovascular accident (ACVA).

Research Methods. Histological examination of the SMC of large hemispheres of rats with the model of ACVA (6 days), caused by occlusion of the left common carotid artery. After removal from the skull, the brain was fixed in $96^{\circ}$ ethanol, then a frontal incision was made at the level of the anterior edges of the temporal lobes. The samples were embedded in paraffin, one part was stained with hematoxylin and eosin, the other with thionine according to the Nissl method. Examination of micropreparations was performed under a Granum light microscope, microphotography of microscopic images - digital video camera Granum DSM 310. Photographs were processed on a Pentium 2.4GHz computer using Toup View.

Results and Discussion. In rats with ACVA in the area of the SMC of the large hemispheres revealed signs of circulatory disorders: spasm of arterioles, venous hyperemia, pericapillary edema; appearance of pyramidal neurons with morphological changes of irreversible nature. An increase in the number of hyperchromic and hypochromic neurons, an increase in the glioneuronal and perineuronal indices and the alteration index were found. The compound KGM-5 improves cerebral circulation in rats with ACVA, as evidenced by a decrease in the severity of capillary spasm and pericapillary edema, increases the survival of pyramidal neurons of the SMC of the brain, reduces the relative proportion of irreversibly altered cells, as evidenced by decreased perineural satellite indices.

Conclusions. The ability of a new derivative of 4-aminobutanoic acid of the compound KGM-5 to improve cerebral circulation, increase the survival of pyramidal neurons, reduce the number of irreversibly altered cells has been established. This proves the presence of compounds KGM-5 cerebroprotective properties, the severity of which it is not inferior to the comparison drug Picamilon.

KEY WORDS: new derivative of 4-aminobutanoic acid; compound KGM-5; model of acute cerebrovascular accident; sensorimotor cortex; drug Picamilon.

Отримано 29.01.21

Адреса для листування: О. Я. Міщенко, Національний фрармацевтичний університет, Інститут підвищення кваліфрікації спеціалістів фрармації, майдан Захисників України, 17, Харків, 61001, Україна, e-mail: mishchoksana@gmail.com. 